\title{
А.О. Красноруцький
}

Харківський національний університет Повітряних Сил ім. І. Кожедуба, Харків

\section{МЕТОД ЗНИЖЕННЯ БІТОВОЇ ШВИДКОСТІ ВІДЕОДАНИХ В ТЕЛЕКОМУНІКАЦІЙНИХ СИСТЕМАХ НА ОСНОВІ КОДУВАННЯ БІТОВОЇ СТРУКТУРИ ТРАНСФОРМАНТИ}

У статті показано, щуо в процесі рімення завдань підвищення продуктивності телекомунікаційних систем виникає необхідність в зменшенні бітової швидкості відеопотоку. Ефективність рішення таких задач залежить від якості надання відеоінформаційних послуг. Проте, на практиці бітова швидкість відеопотоку, збільшується кожен рік, та в даний час перевищує допустимі значення у декілька разів. Основною причиною з одного боку є великі об'єми відеоданих, а з іншого боку обмежені технічні характеристики телекомунікаційних систем. Це приводить до збільшення часу затримки та імовірності втрат пакетів при обслуговуванні пакетів на вузлах комутаиії. Один з напрямків рімення даної суперечності полягає у зменшені об'ємів відеоданих за рахунок використання методів стиску. В статті розроблено методи стиснення $i$ відновлення зображень для зниження бітової швидкості відеопотоку в телекомунікаційних системах, щзо забезпечує зниження часу затримки та імовірності втрат пакетів в умовах обмежень за швидкодію обчислювальних систем та швидкістю передачі даних телекомунікаційних систем.

Ключові слова: бітова швидкість, телекомунікаційні системи, компресія, затримка пакетів, вірогідність втрат пакетів, методи стиснення, позиційно структурно-вагове кодування.

\section{Вступ}

Постановка проблеми. На даний час важливою тенденцією розвитку інфокомунікаційних систем $\epsilon$ розвиток технологій надання відеоінформаційних послуг. При цьому частка обсягу переданого відео трафіку відносно загального об’єму трафіку щорічно зростає і на даний час становить більш ніж 70\% [1]. Це в свою чергу призводить до збільшення бітової швидкості відеоінформаційного потоку, що перевищує темпи вдосконалення характеристик телекомунікаційних систем. Внаслідок цього продуктивність телекомунікаційних систем зменшується відповідно до збільшення бітової швидкості, що є недопустимим для надання відео-інформаційних послуг з належною якістю. Отже, зниження бітової швидкості відеоданих для підвищення якості надання послуг з використанням телекомунікаційних систем $\epsilon$ актуальною науково-прикладною метою.

Аналіз останніх досліджень і публікацій. Ефективним напрямком підвищення продуктивності телекомунікаційних систем за рахунок зниження бітової швидкості є застосування методів компресії. У цьому випадку знижується завантаження вузлів комутації, час затримки й імовірності втрат пакетів на вузлах телекомунікаційних систем, загальний час передачі пакету в мережі [2]. Значний вклад в розвиток теорії та розробки методів стиснення внесли багато вчених. Серед них Корольов А.В., Поляков П.Ф., Бараннік В.В., Красильников М.М., Ряб- ко Б.Я. та ін. Із закордонних дослідників великий внесок внесли Зив Дж., Претт У., Шеннон К., Хартлі Р.Л. та ін.

Проведений аналіз складових технологій компресії стосовно можливості зниження інтенсивності відео потоку дозволив сформулювати основні напрямки їх вдосконалення:

- забезпечити стиснення зображень із контрольованою втратою їх якості з використанням рекурентно реверсного розширеного позиційно структурно-вагового кодування, яке має наступні властивості: обробка проводиться в бітовому представленні трансформант; зменшується кількість операцій; зменшується можливість втрати зображення за рахунок збільшення завадостійкість повідомлень.

- організувати стиснення трансформант розробленим позиційним структурно-ваговим кодуванням на основі виявлення та усунення просторової надлишковості як статистичної та структурної, так і психовізуальної природи.

Мета статті - розробка методу кодування бінарного представлення трансформованих зображень, для зниження їх бітової швидкості із заданою якістю реконструкції з використанням телекомунікаційних систем.

Для досягнення поставленої мети необхідно вирішити наступні завдання:

1. Обгрунтувати напрям вдосконалення технології кодування бінарного представлення трансформант для зниження їх бітової швидкості і часу обро- 
бки без внесення додаткових спотворень.

2. Розробити метод кодування бітового представлення трансформант для підвищення ступеня стиску зображень в умовах збереження заданої якості візуалізації зображень, призначених для передачі в інфокомунікаційних системах реального часу.

3. Створити метод стиснення і відновлення відеоданих, на основі кодування бітового представлення трансформованих зображень, що забезпечують зниження об'ємів зображень із заданою якістю їх візуалізації.

4. Створити програмну реалізацію технологій стиску і відновлення зображень.

\section{Виклад основного матеріалу}

Ситуація яка утворилась в даний час на ринку інфокомунікаційних послуг характеризується перевантаженням телекомунікаційних мереж.

В той же час характеристики існуючих інфокомунікаційних технологій, є значно нижче потрібних. Середній час передачі одного відео кадру в залежності від його просторового розширення досягає десятків хвилин.

Для зниження інтенсивності відео потоку виконується інтеграція в інфокомунікаційні системи технологій компресії, основною характеристикою якої, є бітова швидкість $V(t)_{c}$ відео-інформаційного потоку, а саме:

$$
V(t)_{c}=f_{\tau} M N d-\eta(\sigma i m),
$$

де $f_{\tau}$ - частота кадрів, тобто кількість кадрів відтворених за час $\tau$;

$M, N$ - просторове розширення зображення;

$d$ - кількість біт на один елемент зображення.

Оцінка бітової швидкості від пікового відношення сигнал шум і просторового розширення кадру дозволяє зробити висновок, що існуючі технології як для транспортних мереж так і для мереж доступу не забезпечують передачу відео-потоків 3 високим просторовим розширенням кадрів в режимі реального часу. Отже, зниження бітової швидкості компресованих відеоданих для підвищення якості представлення послуг з використанням засобів телекомунікації, є актуальною науково-прикладною задачею.

Напрямок рішення поставленої задачі полягає у вдосконаленні технології компресії. Сучасні системи стиску відеоданих базуються в основному на використанні JPEG орієнтованих технологій. Для кодування трансформант в JPEG технологіях використовуються два базових підходи, які використовують компонентну та бітову структури трансформант.

Для зменшення бітової швидкості, компресованого потоку, пропонується використання другого підходу. Переваги технології кодування бітового представлення трансформант полягають в наступному: можливість проведення м'якої технології скорочення психовізуальної надлишковості; наявність зон нульових елементів, в незалежності від ступеня насиченості зображення; використання менш потужних алгоритмів для виділення закономірностей бінарної природи; обробка двійкових даних дозволяє спростити апаратну реалізацію кодерів.

У той же час, недоліком бітової обробки трансформант $є$ необхідність витратити додаткову кількість операцій власно на саму бінаризацію кожної компоненти трансформанти, і відповідно внесення додаткових часових затримок на етапах бінаризації i формуванню масивів бітових площин.

Отже, потрібно розробити методи кодування бінарного представлення трансформованих зображень, для зниження їх бітової швидкості з заданою якістю реконструкції з використанням засобів телекомунікації. Для цього необхідно отримати систему $F_{c o m p}\left(\left[Y_{m, n}\right]_{2} ; d\right)$ кодоутворюючих виразів $C(Y)=F_{c o m p}\left(\left[Y_{m, n}\right]_{2} ; d\right)$, які забезпечують мінімізацію бітової швидкості $V(C) \rightarrow \min$, при заданій складності алгоритмізації $q_{c}+q_{r} \leq \arg$ ument $\left(t\left(q_{c}+q_{r}\right)\right)$, тут $t\left(q_{c}+q_{r}\right) \leq q_{p} / t$ i якості реконструйованих зображень $\delta=\max \{\delta(k ; u)\} \geq \delta^{\prime}$.

Процес стиску трансформанти, базується на трьох складових:

- бінарізація компонент трансформанти;

- виявлення просторових закономірностей для двійкового представлення трансформант;

- кодування бітового представлення трансформант.

Бінаризація трансформанти проводиться як формування двійкового куба на базі дискретних значень коефіцієнтів базисних функцій. На другому етапі, формування структурованого опису бітового представлення трансформанти пропонується організовувати виявлення лінійних розмірів двійкових об'єктів бінарних серій.

В результаті такої обробки всіх бітових площин формується масив $A_{k, u}$ бінарних серій: $A_{k, u}=\left\{l_{s, p}\right\}, p=\overline{1, p} \quad$ для $1 \leq s \leq s^{\prime} . \quad p=\overline{1, \psi} \quad$ для $s=S$.

Тут $l_{s, p}-(s, p)$-й елемент масиву $A_{k, u}$;

$P$ - довжина строки (кількість стовбців) в масиві $A_{k, u}$;

$S$ - довжина повного стовбцю;

$s^{\prime}$ - довжина не повного стовбцю.

На третьому етапі пропонується кодувати отримані масиви, на базі формування блокових по- 
зиційних кодів. Для такого представлення розміри двійкових областей враховуються в результаті виявлення довжин двійкових серій, а позиції областей на основі залежності вагових коефіцієнтів довжин серій від їх позиції в бітовому представленні.

Отже дане кодування може інтерпретуватися як позиційно структурне вагове кодування. Проте запропонований підхід кодування має ряд недоліків, що впливають на наявність інформаційної надлишковості, що приводить до підвищення бітової швидкості стислого представлення трансформанти.

Перший недолік полягає в обмеженні значення максимально-допустимої довжини кодового слова. Внаслідок чого структурна надлишковість скорочується не повністю Це задається наступним виразом:

$$
R_{v}=v V_{c}-V(v)_{c}^{\prime}
$$

де $R_{v}$ - кількість надлишковості;

$V(v)_{c}^{\prime}$ - довжина кодового слова розширеного позиційно структурно-вагового числа, що включає $v$-ю кількість початкових позиційно структурновагових чисел;

$v V_{c}$ - сумарний об'єм кодових слів, сформованих для початкових позиційно структурновагових чисел, для кожного окремо.

Вирішення даного недоліку можливе за рахунок формування єдиного коду для розширеного позиційно структурно вагового числа. Це забезпечить скорочення бітової швидкості компактнопредставленого сегменту зображення в середньому на 20-50\% залежно від їх міри насиченості і рівня внесених спотворень.

Другий недолік обумовлений тим що: виявлення бінарної серії обмежене межами окремої бітової плоскості. Це приводить до наявності структурної надлишковості, крім того, правильне визначення меж кодових конструкцій стислого представлення сегментів залежить від безпомилковості виявлення розмірів і початкових позицій кодових конструкцій всіх попередніх сегментів.

Тому для скорочення надлишковості підвищення перешкодостійкості кодових конструкцій стислого представлення сегментів зображень без використання додаткових кодів, потрібно забезпечити режим кодоутвореня, коли довжина кодових слів буде рівномірною для всіх сегментів.

Для усунення недоліків пропонується використовувати рекурентне реверсне кодування розширених позиційно структурно-вагових чисел змінної довжини.

Суть якого полягає в додаванні старшого елементу позиційного числа:

$$
A^{(p)}=\left\{l_{1, p}, \ldots, l_{s, p}, \ldots, l_{S, p}\right\}, \text { при наявності ін- }
$$

формації про кількість і основ лише раніше оброблених елементів.
Якщо вважати, що кожен елемент, що додається, розглядається як молодший елемент відносно ще необроблених, то даний вираз прийме вигляд формула 3.

$$
\begin{gathered}
C\left(S^{\prime}\right)_{p}=l_{1, p}^{\prime} g_{1} \prod_{\xi=2}^{S} g_{\xi}+\sum_{\xi=2}^{S} g_{\xi}+\prod_{\gamma=s+1}^{S} g_{\gamma}= \\
=l_{1, p}^{\prime} g_{1} W_{1}+C(S)_{p},
\end{gathered}
$$

де $S^{\prime}$ - довжина розширеного позиційного структурно-вагового числа;

Принцип реверсного кодування полягає в на тому, що обчислення вагового коефіцієнта для поточного елементу позиційного числа здійснюється шляхом множення вагового коефіцієнта попереднього елементу на його основу (рис. 1), тобто:

$$
W_{s}=\prod_{\xi=1}^{s-1} g_{\xi}=g_{s-1} \prod_{\xi=1}^{s-2} g_{\xi}=g_{s-1} W_{s-1},
$$

де $W_{s}$-ваговий коефіцієнт елементів позиційно структурно-вагових чисел.

Таблиця 1

Схема перерахунку основ елементів розширеного позиційно структурно-вагового числа при додаванні старшого елементу

\begin{tabular}{|c|c|c|c|c|c|c|c|}
\hline$s$ & 1 & 2 & $\ldots$ & $s$ & $\ldots$ & $S$ & $S^{\prime}$ \\
\hline$W_{S}$ & $\prod_{\xi=2}^{S} g_{\xi}$ & $\prod_{\xi=3}^{S} g_{\xi}$ & $\ldots$ & $\prod_{\xi=s+1}^{S} g_{\xi}$ & $\ldots$ & 1 & \\
\hline$W_{S}^{\prime}$ & $g_{1} W_{1}$ & $W_{1}$ & $\ldots$ & $W_{s-1}$ & $\ldots$ & $W_{S-1}$ & 1 \\
\hline
\end{tabular}

Джерело: розроблено автором за даними [2, С. 8].

Це дозволяє зняти обмеження на максимальну довжину бінарної серії і формувати код для розширеного позиційного числа без апріорної інформації про його довжину і значення вагових коефіцієнтів старших елементів.

Довжина позиційного числа вибирається з умови при якому кількість розрядів на представлення максимально можливого значення його коду не перевищує задану довжину кодового слова $v\left(S^{\prime}\right)_{\max } \leq V_{i c}$ (рис. 1), а умова вибору довжини розширеного позиційного числа, так щоб виключити переповнювання кодового слова заданої довжини, задається формулою:

$$
S^{\prime}=\arg \left\{\min _{v\left(S^{\prime}\right)_{\max } \leq V_{i c}}\left(V_{i c}-\left[\sum_{s=1}^{S^{\prime}} \log _{2} g_{s}\right]+1\right)\right\},
$$

де $V_{i c}$ - задана довжина кодового слова;

$$
v\left(S^{\prime}\right)_{\max } \text { - максимальна довжина розширеного }
$$
позиційно структурно-вагового числа. 


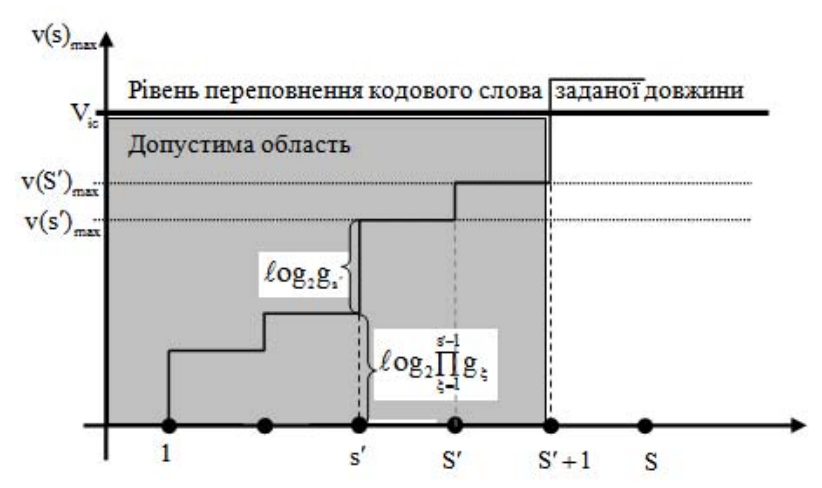

Рис. 1. Діаграма визначення довжини розширеного позиційно структурно-вагового числа Джерело: [7, С. 150].

На кожному кроці обробки потрібно перевіряти умову на допустимість додавання чергового елементу до поточного позиційного числа.

Така обробка зводиться до виконання системи:

$$
D=\left\{\begin{array}{l}
D+1, \rightarrow\left[\sum_{\xi=1}^{D} \log _{2} g_{\xi}+\log _{2} g_{s^{\prime}}\right]+1 \leq V_{i c} ; \\
D=S, \rightarrow\left[\sum_{\xi=1}^{D} \log _{2} g_{\xi}+\log _{2} g_{s^{\prime}}\right]+1>V_{i c},
\end{array}\right.
$$

де $D$ - довжина поточного позиційного структурно-вагового числа;

$\log _{2} g_{s^{\prime}}$ - кількість розрядів, на яку збільшується довжина кодового представлення максимальної коди позиційного структурно-вагового числа довжиною (D+1) елементів;

$$
\sum_{\xi=1}^{D} \log _{2} g_{\xi}-\text { оцінка кількості розрядів, яку по- }
$$

трібно витратити на представлення максимального значення коду для позиційно структурно-вагового числа, що складається з D елементів;

Таким чином розроблене рекурентне реверсне розширене позиційне структурно-вагове кодування, що забезпечує формування кодового значення для числа змінної довжини. Це дозволяє знизити бітову швидкість за рахунок усунення кількості кодової надмірності, і виключити неконтрольовані втрати інформації.

В процесі інтеграції технології кодування в систему компресії зображень необхідно отримати зниження бітової швидкості компактнопредставлених сегментів в умовах забезпечення: заданої якості зображень, що реконструюються; та часової затримки на обробку сегменту.

Попередня обробка в даній схемі, створює можливість для усунення просторової надлишковості, обумовленої психовізуальними особливостями сприйняття зображень зоровою системою.

Подальша обробка трансформанти направлена на усунення просторової надлишковості, обумовленої статистичними і структурними закономірностями трансформанти. Побудова кодових конструкцій стислого представлення бінаризованої трансформанти на базі розробленого позиційного структурновагового кодування здійснюється на третьому етапі.

Даний етап включає процедури, а саме, формування розширених позиційних структурно-вагових чисел змінної довжини; обчислення кодового значення для розширеного позиційного числа; утворення рівномірних кодових конструкцій із заданою битвою завдовжки.

Для реконструкції сегментованих зображень 3 контрольованою погрішністю необхідно враховувати як базові технологічні процеси, так і відмітні особливості технології кодування бінаризованих трансформант.

Метод реконструкції стислих зображень повинен включати наступні концептуальні складові: перша складова виражається в необхідності виділення iз загального кодового потоку той його частині, яка відповідає відновлюваному сегменту, пропонується проводити відновлення трансформанти на основі послідовного виділення кодового значення розширеного позиційно структурно-вагового числа, і подальшій його реконструкції.

Друга складова базується на тому, що кодове значення, що міститься в кодовому слові, дозволяє провести реконструкцію розширеного позиційного структурно-вагового числа. Оскільки довжина для розширеного позиційного числа заздалегідь невідома, то для його відновлення пропонується використовувати рекурентну схему. Для здобуття довжини позиційного числа використовується інформація про заздалегідь задану довжину кодового слова і вектор основ. В результаті здобуття окремих бітових площин формується двійкова структура трансформанти. Приведення трансформанти з бітового опису в компонентне організовується на основі третьої складової. Її суть полягає в набутті абсолютних значень компонент на основі бітового розкладання.

Здобуття зображень досягається на основі виконання зворотних трансформаційних процесів i збірки окремих сегментів (десегментації).

Таким чином створений метод відновлення зображень, що забезпечує їх декомпресію 3 контрольованими погрішностями, забезпечує виключення неконтрольованих втрат інформації в умові зниження бітової швидкості.

Оцінка бітової швидкості для розробленої технології компресії проводитися на основі формули:

$$
V(t)_{c}=\left(\left[\sum_{s=1}^{S} \log _{2} g_{S}\right]+1\right) \sum_{k=1}^{K} \sum_{u=1}^{U} \mu_{k u},
$$

де $K$ - кількість сегментів відеоданих по вертикалі;

$U$ - кількість сегментів відеоданих по горизо- 
нталі;

$S$ - довжина позиційного структурно-вагового числа;

$\mu_{k u}$ - кількість кодограм в одному сегменті трансформованого зображення.

Порівняльна оцінка бітової швидкості для розробленого методу стискування і методу стискування на основі JPEG технології представлена у вигляд діаграмми на рис. 2.

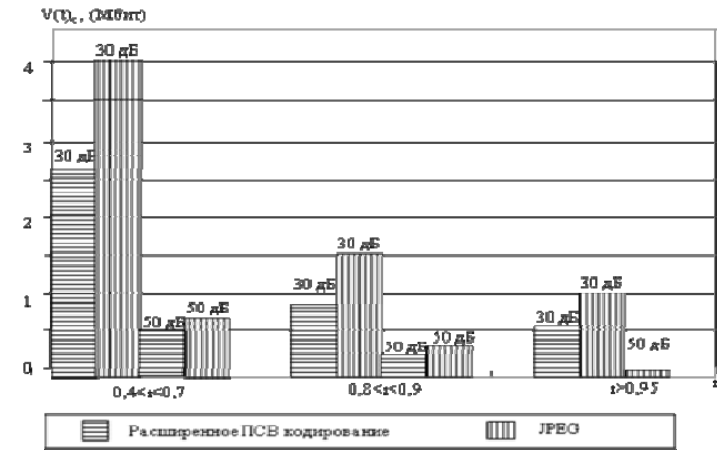

Рис. 2. Порівняльний аналіз залежності величини бітової швидкості від міри насиченості зображення для технології позиційно структурно-вагового кодування і JPEG методу компресії.

Джерело: розроблено автором за даними [5, С. 49].

Аналіз даної діаграми дозволять стверджувати, що використання розробленого кодування дозволяє отримати виграш по бітовій швидкості відносно
JPEG технології залежно від рівня спотворень, що вносяться, в середньому на $50 \%$. Часові витрати на стискування зображень 3 використанням позиційний структурно вагового кодування виявляються в середньому на 55\% меншими, ніж для JPEG орієнтованих методів, що показане на рис. 3.

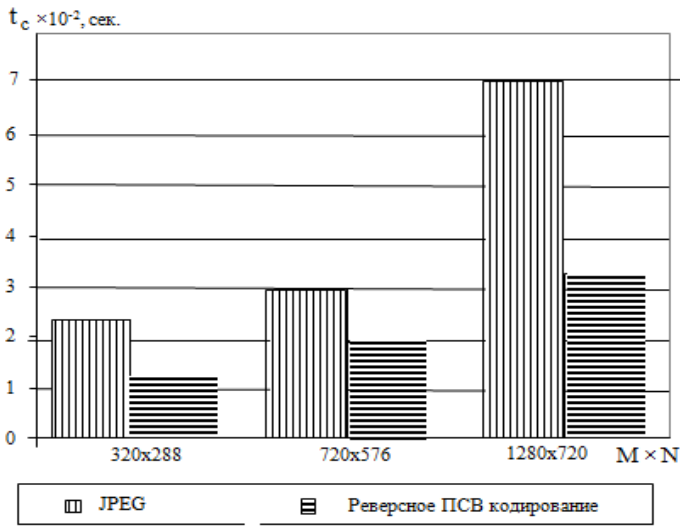

Рис. 3. Діаграма залежності часових витрат на реалізацію позиційно структурно-вагового кодування і JPEG технології від просторового розширення кадру

Джерело: розроблено автором за даними [8, С. 39].

Оцінка показників продуктивності телекомунікаційної мережі з врахуванням впливу бітової швидкості, а саме: час затримки на вузлі комутації, ймовірність втрати пакетів, сумарний час доставки пакету, проводиться відповідно до формул 8, 9.

$$
\begin{aligned}
& \tau_{\text {jnWiMax }}=\left(\tau_{j \max \text { WiMax }}-\right. \\
& \left.-\frac{1}{V(t)_{c} /\left(\left(\left[\frac{V(t)_{c}}{l_{\text {iWiMax }}}\right]+1\right)\left(t_{1 \text { WiMax }}+t_{2 \text { WiMax }}+t_{3 \text { WiMax }}\right)\right)+\frac{1+C_{b}^{2}}{2 t_{i}}}\right) n_{j} \text {; } \\
& P_{\text {OWiMax }} j=\frac{1-\frac{\left(\left\lfloor\frac{V(t)_{c}}{l_{\text {WWiMax }}}\right\rfloor+1\right)\left(t_{1 \text { WiMax }}+t_{2 \text { WiMax }}+t_{3 \text { WiMax }}\right)}{\varepsilon}}{1-\left(\frac{\left(\left\lfloor\frac{V(t)_{c}}{l_{\text {iWiMax }}}\right\rfloor+1\right)\left(t_{1 \text { WiMax }}+t_{2 \text { WiMax }}+t_{3 \text { WiMax }}\right)}{\varepsilon}\right)^{N_{u}+1}},
\end{aligned}
$$

де $\tau_{j n W i M a x}-$ максимальна тривалість обслуговування одного $n$-го пакету на $j$-му вузлі комутації;

$l_{i}-$ об’єм інформаційної частини одного пакету (біт);

$C_{b}^{2}$ - квадрат коефіцієнта варіації 0,2;

$t_{i}$ - часовий інтервал між пакетами; $t_{1}$ - часовий інтервал, займаний передачею інформаційної частини пакету;

$t_{2}$ - часовий інтервал, займаний передачею службової частини пакету;

$t_{3}$ - середній час затримки пакету в мережі доступу; 
$\varepsilon$ - продуктивність вузла комутації (біт/с). I представлено на рис. 4, 5.

3 аналізу яких можна зробити наступні висновки. Використання позиційне структурновагового кодування дозволяє: перше знизити часову затримку при обробці сильно і слабо насичених реалістичних зображень відповідно від 42\% до 50\%, для пікового відношення сигнал-шум на рівні 30 дБ відносно JPEG методу компресії; друге для сильно насичених зображень дозволяє за рахунок зменшення бітової швидкості відео-потоку, знизити імовірність втрати пакетів в мережі WiMax в середньому на 25\%, при пікового відношення сигнал-шум 30дБ відносно JPEG метода.

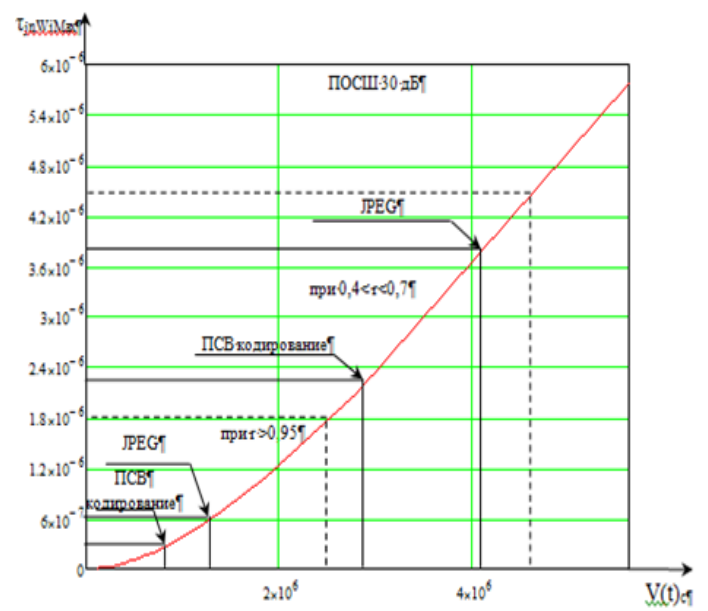

Рис. 4. Залежність часу затримки на $n$-му вузлі комутації повідомлень від бітової швидкості в мережі WiMax для JPEG методу стискування і позиційно структурно-вагового кодування при ПВСШ 30дБ Джерело: розроблено автором за даними [3, С. 46].

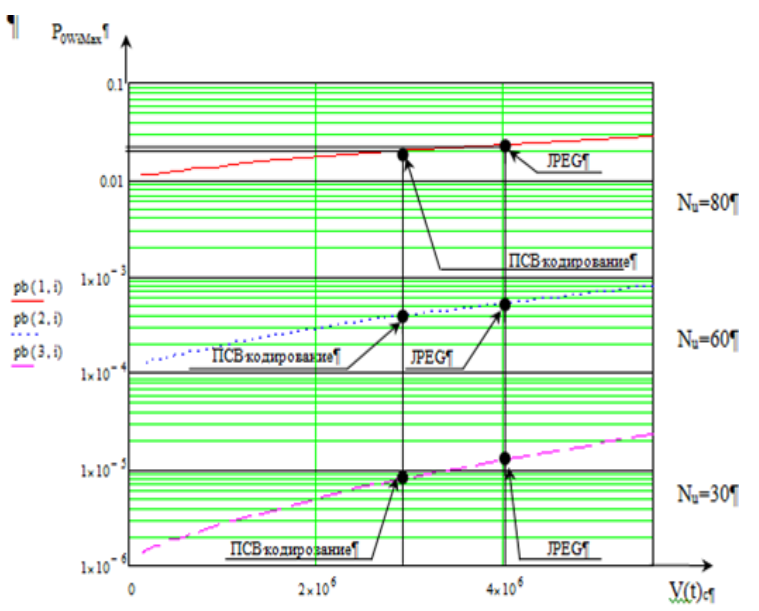

Рис. 5. Залежність імовірності втрат пакетів від бітової швидкості V(t)c JPEG методу стискування

і позиційно структурно-вагового кодування при ВСШ 30дБ для технології WiMax

Джерело: розроблено автором за даними [3, С. 45].
Таким чином, навіть при одному відсотку втрат, зображення до якого застосовувалося JPEG метод компресії втрачає свою значущість. А зображення, до якого застосовувалося позиційно структурно-вагове кодування володіє більшою стійкістю до втрат пакетів. Дані результати дозволяють обгрунтовано стверджувати відносно можливості і доцільності інтеграції розробленого позиційно структурновагового кодування, як складового елементу механізму компресії, в телекомунікаційні системи на базі безпровідних технологій, 3 метою підвищення їх продуктивності.

\section{Висновки}

В статті вирішено актуальну науковоприкладну задачу, яка пов'язана з розробкою методу зниження бітової швидкості скомпресованих відео даних для підвищення якості надання відеоінформаційних послуг з використанням телекомунікаційних систем. Розроблено метод зниження бітової швидкості відеоданих на основі позиційного структурновагового кодування. Стиснення трансформант досягається шляхом формування розширених позиційно структурно-вагових кодів, які враховують особливості обробки бінарної системи трансформант.

Основними отриманими науковими результатами є:

1. Розроблено метод компресії зображень на основі формування коду, починаючи з молодших елементів та реалізації перехресного порядку відповідності між елементами нерівновісних поліадичних чисел і елементами стовбців масивів довжин серій двійкових елементів.

2. Створено метод відновлення зображень, який забезпечує їх декомпресію з контрольованими погрішностями 3 позиції спотворення якості візуалізації, виключення неконтрольованих втрат інформації в умові зниження бітової швидкості.

3. Створено метод підвищення продуктивності телекомунікаційних систем на основі зниження бітової швидкості вхідного відеопотоку шляхом позиційно структурно-вагового кодування та скорочення обсягу зображень.

4. Створено модель оцінки характеристик продуктивності телекомунікаційних систем, яка дозволяє додатково врахувати вплив на інтенсивність, розміри пакетів і буферних пристроїв величини ступеня стиску вхідного відеопотоку.

Достовірність підтверджується результатами експериментальних досліджень щодо зниження бітової швидкості відеопотоку із заданими характеристиками по оперативності його формування і якості реконструкції зображень, а також їх відповідності результатам теоретичних досліджень, отриманими на основі математичних моделей оцінки характеристик продуктивності телекомунікаційних систем. 


\section{Список літератури}

1. Баранник В.В. Позиционное структурно-весовое кодирование бинарного представления трансформант / В.В. Баранник, А.А. Красноруцкий, А.В. Хаханова // Автоматизированные системы управления и приборы автоматики. - 2011. - № 157. - 23-28.

2. Баранник В.В. Методология совершенствования структурно-весового кодирования трансформант для передачи изображений в телекоммуникационных системах / В.В. Баранник, В.В. Бенера, А.А. Красноруцкий // Сучасна спеціальна техніка. - 2012. - № 4(31). - С. 5-13.

3. Красноруцкий А.А. Анализ влияния процесса сжатия видеоинформации на основе характеристики телекоммуникационной сети / А.А. Красноруцкий, А.В. Ширяев // Сучасна спеціальна техніка. - 2012. - № 1(28). - С. 42-48.

4. Красноруцкий А.А. Обоснование проблемных сторон видеоинформационного обеспечения в системе поддержки и принятия решений / А.А. Красноруцкий, И.Е. Рогоза // Сучасна спеціальна техніка. - 2012. - № 2(29), - С. 46-51.

5. Баранник В.В. Обоснование базовой технологии компрессии изображений с заданным качеством визуализации / В.В. Баранник, А.А. Красноруцкий, И.Е. Рогоза // Информационно-управляющие системы на железнодорожном транспорте. - 2013. - №2. - С.41-45.

6. Красноруцкий А.А. Построение правила формирования позиционных структурно-весовых чисел в условиях кодообразования по заданной длине / А.А Красноруцкий // Сучасна спеціальна техніка. - 2012. - № 3(30). - С. 53-56.

7. Баранник В.В. Метод реверсного кодирования структурно-весовых чисел для снижения битовой скорости видеопотока / В.В. Баранник, А.А. Красноруцкий // Захист інформації. - 2013. - № 2. - С. 148-158.

8. Яковенко А.В. Метод оценки битовой скорости видеопотока для технологии структурно-весового кодирования / А.В. Яковенко, А.А. Красноруцкий // Сучасна спеціальна техніка -2013. - № 3(30). - С.43-46.

9. Декомпресоване подання зображень на основі реконструкції бінарної структури трансформант / В.В. Баранник, П.М. Гуржій, А.А. Красноруцкий, I.Є. Рогоза // VI Науково-технічна конференція "Пріоритетні напрямки розвитку телекомунікаційних систем та мереж спеціального призначення”. - Київ, 25-26 жовтня 2012 р. - С. 46.

10. Баранник В.В. Обоснование концептуальных составляющих метода сжатия трансформант с использованием её бинаризации / В.В. Баранник, А.А. Красноруцкий, А.А. Подорожняк // ХІІ Международная научно-техническая конференция “Проблемы информатики и моделирования". - Харьков-Ялта, 2012. - С. 5.

11. Баранник В.В. Методологические основы технологии компрессии трансформированных изображений для телекоммуникаций / В.В. Баранник, А.А. Красноруцкий, И.Е. Рогоза // XXV-я Международная научно-практическая конференция "Перспективные компьютерные, управляющие и телекоммуникационные системы для железнодорожного транспорта Украины”. - Алушта, 2012. - С. 80-81.

12. Баранник В.В. Обоснование подхода для кодирования бинаризированных трансформант зображений / В.В. Баранник, А.А. Красноруцкий, А.К. Юдин // III Міжнародна науково-практична конференція “Інформаційні технології та комп’ютерна інженерія”. - Вінниця, 29-31 травня 2012 р. - С. 47.

13. Баранник В.В. Технология структурно-весового кодирования бинарного представления трансформант / В.В. Баранник, А.А Красноруцкий // ІІІ Міжнародна науково-практична конференція "Інформаційні технології та захист інформації. - Харків, 20-21 квітня 2012 р. - С. 187.

14. Бараннік В.В. Спосіб кодування бінарного представлення трансформант / В.В. Бараннік, А.О. Красноруцький // VIII наукова конференція Харківського університету Повітряних Сил ім. І. Кожедуба "Новітні технології - для захисту повітряного простору”. - Харків, 15-16 лютого 2012 р. - С.47.

15. Баранник В.В. Построение позиционного структурно-весового кодирования бинарного представления трансформант / В.В. Баранник, А.А. Красноруцкий, И.Е. Рогоза // Науково-методична конференція "Сучасні проблеми телекомунікацій і підготовка фахівців в галузі телекомунікацій”. - Львів, 1-4 листопада 2012 р. - С. 106.

16. Krasnorutskij A. Method Structural-Weight Encoding in Position Base Of Binary Description Transformed Images / A. Krasnorutskij, A. Slobodyanyuk, A. Shiryaev // XII-th International Conference "The Experience of Designing and Application of CAD Systems in Microelectronics (CADSM 2013)". - Lviv, 2013. - P. 336-338.

17. Barannik V. The Positional Structural-Weight Coding of the Binary View of Transformants / V. Barannik, A. Hahanova, A. Krasnorutskij // International Symposium "IEEE East-West Design \& Test". - Kharkiv, 18-21 September 2012. - P. 490-494.

18. Демедецкий А.О. Метод компрессии трансформированных изображений на основе кодирования битовых плоскостей трансформант / А.О. Демедецкий, А.А. Красноруцкий // XXIII-я Международная научно-техническая конференция конференция “СВЧ техника и телекоммуникационные технологии”. - Севастополь, 8-14 сентября 2013 г. - С. 396.

19. Demedetskiy A.O. Method of Coding Bitmap Transformant to Improve Image Compression while Maintaining a Predetermined Quality Image to be Transmitted in Infocommunication Real Time Systems / A.A. Krasnorutskij, A.V. Hahanova // XIth IEEE East-West Design \& Test Symposium (EWDTS'2013). - Rostov-on-Don, 27-30 September, 2013. - P. 461-464.

20. Кулик И.А. Метод оценки границ применения сжатия на основе двоичных биномиальных чисел / И.А. Кулик, А.И. Новгородцев, М.С. Шевченко // Системи обробки інформації. - 2019. - № 2(157). - С. 57-62. https://doi.org/10.30748/soi.2019.157.07.

21. Система передачі та відображення інформації із захистом числових даних / О.А. Борисенко, О.В. Бережна, А.І. Новгородцев, В.В. Сердюк, М.М. Яковлев // Системи обробки інформації. - 2019. - № 2(157). - С. 103-108. https://doi.org/10.30748/soi.2019.157.14.

22. Гапон А.О. Підходи до побудови моделі загроз для аналізу безпеки відкритого програмного коду / А.О. Гапон, 
В.М. Федорченко, А.О. Поляков // Системи обробки інформації. - 2020. - № 1(160). - С. $128-135$. https://doi.org/10.30748/soi.2020.160.17.

23. Левченко О.В. Концептуальні основи формування системи забезпечення інформаційної безпеки / О.В. Левченко // Наука і техніка Повітряних Сил Збройних Сил України. - 2018. - № 1(30). - С. 7-12. https://doi.org/10.30748/nitps.2018.30.01.

24. Орлов С.В. Обгрунтування показників якості прийнятих рішень на основі оцінки вихідних даних / С.В. Орлов, А.І. Авілов // Системи озброєння і військова техніка. - 2020. - № 2(62). - С. 35-39. https://doi.org/10.30748/soivt.2020.62.04.

\section{Відомості про автора:}

Красноруцький Андрій Олександрович кандидат технічних наук доцент кафедри Харківського національного університету Повітряних Сил ім. І. Кожедуба, Харків, Україна https://orcid.org/0000-0002-4318-2217

\section{Information about the author:}

\author{
Andrii Krasnorudskyi \\ Candidate of Technical Sciences Senior Lecturer \\ of Ivan Kozhedub Kharkiv \\ National Air Force University, \\ Kharkiv, Ukraine \\ https://orcid.org/0000-0002-4318-2217
}

\title{
МЕТОД СНИЖЕНИЯ БИТОВОЙ СКОРОСТИ ВИДЕОДАННЫХ В ТЕЛЕКОММУНИКАЦИОННЫХ СИСТЕМАХ НА ОСНОВЕ КОДИРОВАНИЯ БИТОВОЙ СТРУКТУРЫ ТРАНСФОРМАНТ
}

\author{
А.А. Красноруцкий
}

В статье показано, что в процессе решения задачи повышения продуктивности телекоммуникационных систем, возникает необходимость в уменьшении битовой скорости видеопотока. Эффективность решения таких задач зависит от качества предоставления видеоинформационных услуг. Однако на практике битовая скорость видеопотока увеличивается в несколько раз каждый год и в текущее время превышает допустимое значение. Основной причиной этого, с одной стороны, является большой объем видеоданных, а с другой, ограничение технических характеристик телекоммуникачионных систем. Это приводит к увеличению временных задержек и вероятности потери пакетов при обслужсивании их на узлах коммутации. Одним из направлений решения данной проблемы является уменьшение объемов видеоданных за счет использования методов сжатия. В диссертационной работе разработан метод сжатия и восстановления изображений для снижения битовой скорости видеопотока в телекоммуникационных системах, что обеспечивает снижение временной задержки и вероятности потери пакетов в условиях ограничения быстродействие вычислительных систем и битовой скорости на передачу данных в телекоммуникационных системах.

Ключевые слова: битовая скорость, телекоммуникационные системы, компрессия, задержка пакетов, вероятность потерь пакетов, методы сжатия, позиционное структурно-весовое кодирование.

\section{METHOD DECLINES INTENSITY OF VIDEO STREAM FOR THE TELECOMMUNICATION SYSTEMS PRODUCTIVITY INCREASE}

\section{A. Krasnorudskyi}

The article shows that, that in the process of tasks decision of the productivity increases of the telecommunication systems there is a necessity for decline diminishing intensity of video stream. Decision efficiency of such tasks depends on quality of video information services grant, which must be well-to-do. However, in practice intensity of video stream, that arises up, increased every year and exceeds necessary values. Principal reason is from one side large volumes of video information's, and technical descriptions of the telecommunication systems are limited. It brings to the increase of time delays over and probabilities of packages losses at service on the knots of commutation. One of directions of decision of this contradiction consists in diminished volumes of video information's due to the use methods of compression. In dissertation work the methods of compression and proceeding in images are developed for the decline of intensity of video stream in the telecommunication systems, that provides the decline of delay time and probability of packages losses in the conditions of limitations on the fast-acting of the computer systems and transmission speed of these telecommunication systems.

Keywords: telecommunication systems, intensity, video information's services, productivity, delay of packages, authenticity of packages losses, methods of compression, wavelet-transform, two dimension polyadic code. 